\title{
Forecasting the economic impacts of two biofouling invaders on aquaculture production of green- lipped mussels Perna canaliculus in New Zealand
}

\author{
Tarek Soliman $^{1,2, *}$, Graeme J. Inglis ${ }^{1}$ \\ ${ }^{1}$ The National Institute of Water and Atmospheric Research Ltd, 10 Kyle Street, Riccarton, Christchurch 8011, New Zealand \\ ${ }^{2}$ Present address: Landcare Research, Private Bag 92170, Auckland Mail Centre, Auckland 1142, New Zealand
}

\begin{abstract}
Resource managers must weigh the costs of preventing biological invasions against the harm that may eventuate from inaction. The costs of intervention are assured, but impacts are typically uncertain. Quantifying the expected economic impacts of invaders before they occur is a pivotal element in justifying expenditure on intervention. We forecast the cumulative economic impacts of 2 invasive biofouling species (Styela clava and Sabella spallanzanii) on New Zealand green-lipped mussel Perna canaliculus aquaculture by combining outputs from an infestation model and ecosystem energy budget model with partial budgeting and equilibrium models. Simulations considered the direct and combined economic impacts of each species on producers and on export markets for the shellfish. Direct impacts on producers were estimated at NZ\$23.9 million (Styela clava), \$14 million (Sabella spallanzanii) and \$26.4 million (both species combined), over a $24 \mathrm{yr}$ period. Societal impacts at the market level were $\$ 10.2, \$ 8$ and $\$ 10.7$ million, respectively. The societal impacts reflect changes in producer and consumer surplus after adjustment to altered market prices. Uncertainty boundaries of the estimates were \$7.4-91.9, \$2.5-56.7 and \$7.4-99.7 million, respectively. We assumed that there are few strong alternatives to the New Zealand product on the world market. Producers therefore benefit from any increase in export price by partially shifting production losses caused by the invaders to foreign consumers. Relaxing this assumption produced greater societal impacts (\$13.3 million). Slowing the spread of the pests, reducing densities and enhancing the premium market position of green-lipped mussels could significantly mitigate the potential impacts.
\end{abstract}

${ }^{*}$ Corresponding author: solimanT@landcareresearch.co.nz

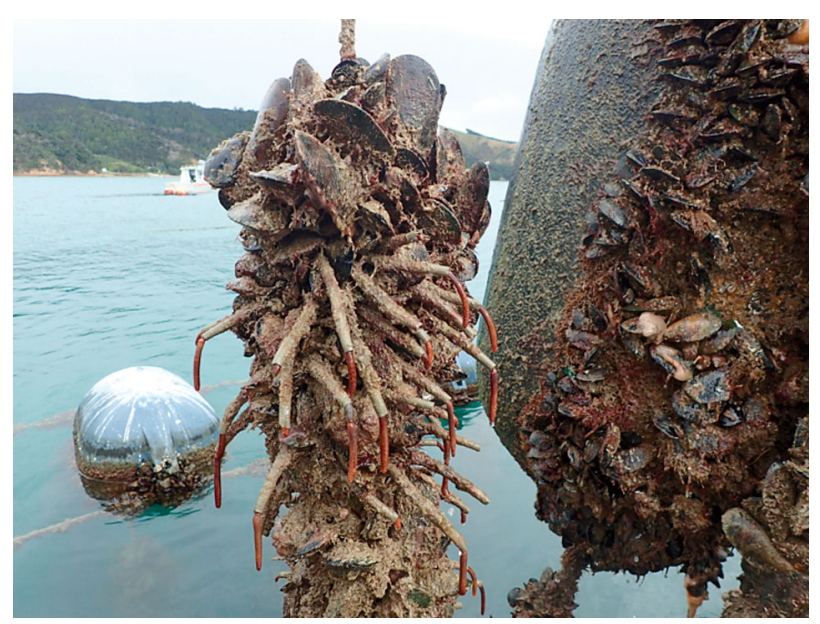

The Mediterranean fan worm fouls a line of green-lipped mussels in New Zealand's Hauraki Gulf. The worm can grow to $80 \mathrm{~cm}$ long and attain densities of 500-1000 $\mathrm{m}^{-2}$.

Photo: Kathy Walls, Ministry for Primary Industries

KEY WORDS: Bio-economic modelling - Marine invasive species - Pest risk analysis - Styela clava . Sabella spallanzanii

\section{INTRODUCTION}

Being able to anticipate and forecast the impacts of invasive species is necessary to ensure that management actions are prioritized toward the species and situations in which they will provide the best outcomes for society (Hulme et al. 2013). Bioeconomic analyses of potential impacts can provide compelling

(C) The authors 2018. Open Access under Creative Commons by Attribution Licence. Use, distribution and reproduction are unrestricted. Authors and original publication must be credited. 
inputs to these decisions (Leung et al. 2002, Lodge et al. 2016), but require quantitative information on the effects of invaders on primary industries, biodiversity, human health or other values at risk. Despite the large increase in research effort on biological invasions over the past 2 decades (Richardson \& Pyšek 2008, Simberloff et al. 2013), our knowledge of the impacts of marine invaders remains patchy and is often based on anecdote and supposition rather than empirical study (Katsanevakis et al. 2014, Ojaveer et al. 2015). A consequence is that there have been relatively few attempts to quantify the economic consequences of marine invasions (Williams \& Grosholz 2008). The lack of evidence of substantive impacts can undermine the willingness of government to commit resources to the management, particularly when public expenditure is prioritized against the more visible, quantifiable and immediate damage done by invasive species in agricultural and terrestrial ecosystems (Cook et al. 2011).

In this study, we used a range of information sources to develop an economic forecast of the potential long-term ( $24 \mathrm{yr})$ effects of 2 recently arrived biofouling invaders on green-lipped mussel Perna canaliculus aquaculture in New Zealand (NZ). Green-lipped mussels account for $\sim 76 \%$ of the total export value of NZ aquaculture ( NZ\$281 million) and comprise about $17 \%$ of NZ's total seafood exports by value (Ministry for Primary Industries 2016b). Biofouling organisms (indigenous and non-indigenous) impose significant costs on shellfish aquaculture by affecting the survivorship, growth and market value of the product (Adams et al. 2011, Forrest \& Atalah 2017). In suspended culture systems, heavy growths reduce water flow and nutrient supply to stock and increase the weight and drag on growing systems (Giles \& Pilditch 2006, Fitridge et al. 2012, Lacoste \& Gaertner-Mazouni 2015). The costs of controlling biofouling in shellfish aquaculture have been estimated at $15-20 \%$ of the total operating costs (Watson et al. 2009, Adams et al. 2011). Invasive biofouling species add significantly to this burden, as they often occur in much greater density and biomass on farmed systems than on native plant and animal marine species (Padilla et al. 2011).

An increasingly diverse range of non-indigenous biofouling organisms, including algae (Forrest \& Blakemore 2006, Pochon et al. 2015), tunicates (Fletcher et al. 2013) and marine worms (Read \& Handley 2004), have affected the NZ mussel industry. They accumulate on the mussel long-line culture systems and shells of the mussels, increasing the costs of production and potentially reducing the den- sity and growth of stock (Woods et al. 2012, Fletcher et al. 2013). Two recent arrivals, the clubbed tunicate Styela clava and the Mediterranean fanworm Sabella spallanzanii, represent potentially serious threats. $S$. clava is a significant pest of mussel aquaculture in Canada, where it forms heavy infestations on seed socks and growing lines (Thompson \& MacNair 2004, Arsenault et al. 2009). The effects of $S$. spallanzanii on bivalve culture are less known, but it is capable of reaching densities of up to 700 ind. $\mathrm{m}^{-1}$ longline in its native range (Giangrande et al. 2014) and, by virtue of its large size and filtration capacity (Lemmens et al. 1996), may be a significant competitor for space and planktonic food.

S. clava was first reported in Auckland, NZ, in 2005 (Davis \& Davis 2006). It has since been detected in a range of other NZ shipping ports and marinas (Riding et al. 2015). Although it is present on some greenlipped mussel farms in the Coromandel Peninsula on the North Island of NZ (an area that accounts for $\sim 22 \%$ of current mussel production), it has yet to infest the main growing area (Pelorus Sound) in the upper South Island where $\sim 68 \%$ of production occurs (Morrisey et al. 2011).

S. spallanzanii was detected by a national surveillance programme in the ports of Lyttelton in 2008 and Auckland in 2009 (Read et al. 2011). It has since been detected on vessels and at low densities on structures in several other NZ ports (Riding et al. 2015). S. spallanzanii has been reported from mussel farms near Auckland and on the Coromandel Peninsula, but is not yet widespread. Past studies have shown that population development and dispersal of both species can accelerate rapidly when environmental conditions are suitable (Lambert \& Lambert 1998, 2003, Currie et al. 2000; Fig. 1).

The potential economic impacts of $S$. clava and $S$. spallanzanii could include direct effects on the quantity and quality of mussels, additional control costs and indirect effects from export losses and changes in producer and consumer incomes due to price changes (Soliman et al. 2010). As the magnitude of the effects could vary across space and time, the potential of these species to pose major impacts on the mussel industry is real. It is therefore important to estimate the possible economic impacts and their level of uncertainty in order to help design economically justified interventions. Two earlier studies attempted to quantify the impacts of $S$. clava on NZ aquaculture (NZIER 2005, Deloitte 2011). Both were premised on bestguess assumptions for the rate of spread and expected damage and examined only direct impacts on mussel production. In this study, we estimated the 


\section{Direct economic impacts at the producer level}

The direct economic impacts consist of the market value of the mussel weight loss and the additional on-farm control costs that resulted from the presence of S. clava and S. spallanzanii (Table 2). A partial budgeting technique was used to estimate the direct economic impacts as follows (Soliman et al. 2010):

$$
\mathrm{DEI}=\sum_{t=1}^{n} p w\left(a_{t}\right)+c\left(a_{t}\right)
$$

where DEI is the expected direct economic impact at time $t, p$ is the market price, $w$ is the mussel weight loss, $C$ is the additional control cost, and $a_{t}$ is the area affected at time $t$. The annual value of the mussel weight loss is estimated by multiplying the rate of reduction in mussel weight, the annual total production of the infested area and the market value of mussels. The market value of half-shell mussels was used in our economic model, as the majority of the produced mussels are exported as frozen half-shell mussels (Aquaculture New Zealand 2012).

We used outputs from a biofouling-aquaculture ecosystem model to estimate the effects of $S$. clava and $S$. spallanzanii on mussel growth. The model is built upon an existing shellfish (green-lipped mussel) DEB ecosystem model that was developed to predict mussel production in response to variation in water flux, nutrient availability, mussel energetics and population dynamics (Ren et al. 2010). The model was extended by J. Ren et al. (unpubl.) by coupling it with DEB sub-models for $S$. clava and $S$. spallanzanii, and other common biofouling species on mussel lines (wild green-lipped mussels, blue mussels Mytilus galloprovincialis and solitary ascidians [predominantly Ciona intestinalis]). The model assumes that phytoplankton is the main food source for mussel energetics and growth. Biofouling organisms would reduce food availability to mussels, as they compete for the same type of food sources. The coupling takes into account the interactions between these filter feeders and the environment. Initially, the model was run for a standard mussel farming practice without biofouling organisms. The results showed that it successfully reproduced ecosystem behaviours. Once the biofouling organisms were considered in the model, the results indicated that co-occurrence of both species would significantly affect the farming ecosystem through biodeposition as well as mussel growth. In our analysis, the model was used to simulate the effects of 3 different densities of $S$. clava and $S$. spallanzanii, i.e. 50, 100 and 500 ind. $\mathrm{m}^{-1}$ longline, in 2 Pelorus Sound growing areas: Port Ligar $\left(40.9208^{\circ} \mathrm{S}, 173.9853^{\circ} \mathrm{E}\right)$ and Nydia Bay $\left(41.1735^{\circ} \mathrm{S}, 173.7748^{\circ} \mathrm{E}\right)$. In each area, simulations examined 3 different scenarios: (1) where only $S$. clava was present on the mussel longlines, (2) where only $S$. spallanzanii was present and (3) where the 2 invaders co-occurred.

Depending on the modelled density (ind. $\mathrm{m}^{-1}$ of longline), the simulations showed that the presence of $S$. clava reduced mussel mass by between 6.1 and $39.3 \%$. S. spallanzanii reduced mussel biomass by 1.3-12.1\%. Both species combined reduced mussel biomass by between 6.1 and $44 \%$ (J. Ren et al. unpubl.). For our analysis, we used the mean value for the loss of mussel mass at the 2 growing locations at densities of 100 ind. $\mathrm{m}^{-1}$ of longline. Scenarios with 50 and 500 ind. $\mathrm{m}^{-1}$ of longline were used for the sensitivity analysis. Deloitte (2011) estimated that production costs represent $45 \%$ of the revenues. With an assumption that the additional control costs represent $20 \%$ of the production costs, the additional control costs are then estimated at $9 \%$ of the revenues (Deloitte 2011). The present value of the total direct economic impacts is then estimated after discounting the impacts at a rate of $8 \% \mathrm{yr}^{-1}$ and assuming that the mussel production will increase at a rate of $3 \% \mathrm{yr}^{-1}$ (Bell \& Yap 2008, NZIER 2010).

Table 2. Data inputs for the partial budgeting model used to estimate the direct economic impacts consisting of the market value of green-lipped mussel weight loss and the additional on-farm control costs that resulted from the presence of Styela clava and Sabella spallanzanii

\begin{tabular}{|lccl|}
\hline Assumption & Unit & Value & Source \\
\hline Pest population density & ind. $\mathrm{m}^{-1}$ longline & 100 & J. Ren et al. (unpubl.) \\
Additional control costs & $\%$ & 9 & Deloitte (2011) \\
Mussel weight loss rate for Styela clava & $\%$ & 10.65 & J. Ren et al. (unpubl.) \\
Mussel weight loss rate for Sabella spallanzanii & $\%$ & 2.5 & J. Ren et al. (unpubl.) \\
Mussel weight loss rate for Styela clava and Sabella spallanzanii & $\%$ & 12.65 & J. Ren et al. (unpubl.) \\
Discount rate & $\%$ & 8 & Bell \& Yap (2008) \\
International price of mussels & $\mathrm{NZ} \$ \mathrm{t}^{-1}$ & 5718 & Aquaculture New Zealand (2012) \\
Annual growth rate of mussel production & $\%$ & 3 & NZIER (2010) \\
\hline
\end{tabular}




\section{Total (direct and indirect) societal impacts at the market level}

The societal impacts are the changes in the producer and consumer surpluses that result from a change in the price of mussels. Changes in the domestic (or international) prices of mussels are a result of changes in the quantities supplied (or exported) and demanded (or imported) in the domestic (or international) market, which is in turn affected by the presence of $S$. clava and $S$. spallanzanii in the marine farming areas. The sum of the changes in consumer and producer surpluses is equivalent to changes in total societal welfare (Table 3 ).

Partial equilibrium (PE) modelling was used to capture the societal effects. In this study, we employed the PE model used by Soliman et al. (2012). It consists of 2 regions: $\mathrm{NZ}$ and the rest of the world (ROW). We assumed that (1) mussels in NZ and in the ROW are perfect substitutes and their respective prices differ only in the transportation costs, and (2) the NZ mussel market is perfectly competitive.

Within the PE model, the demand and supply in NZ are defined by Eq. (4a-g) below (Surkov et al. 2009). Eq. (4a) describes the demand $\left(D_{i}\right)$ in the domestic market as a function of the domestic price $\left(P_{i}\right)$, where $\eta_{i}$ is the price elasticity of demand, and $\chi_{i}$ is a scale parameter. The supply in the domestic market $\left(S_{i}\right)$ has 2 components (Eq. 4b): supply by affected producers $\left(S A_{i}\right)$ and supply by non-affected producers $\left(S N_{i}\right)$. The supply by non-affected producers $\left(S N_{i}\right)$ depends on the price $P_{i 1}$ with supply elasticity $\theta_{i}$ and scale parameter $\beta_{i}$, and is also determined by the proportion of producers $\left(z_{i}\right)$ that is not affected by the invasive spe- cies $\left(1-\mathrm{z}_{i}\right)$. Further, the supply by affected producers $\left(S A_{i}\right)$ depends on the proportion of mussel weight loss, $h_{i}$, caused by the invasive species, and by the reduced net price for the product that affected producers experience as a result of increased costs of production $v_{i}$ (e.g. for control or sanitation) (Eq. 4d). Prices in the domestic $\left(P_{i}\right)$ and world market $\left(W P_{i}\right)$ are linearly related, where $\mu_{i}$ represents transport costs (Eq. 4e). The market value of the half-shell mussels was used to express these market prices. The equilibrium condition for international trade is expressed by Eq. $(4 \mathrm{f}, \mathrm{g})$. Eq. (4f) calculates exports $\left(X_{i}\right)$ as the difference between domestic supply and demand. Eq. (4g) expresses the relationship between international trade and the world price $\left(W P_{i}\right)$, where $v_{i}$ is a scale parameter, and $\omega_{i}$ is export elasticity (see Table A1 in the Appendix for calculation of the export elasticity).

$$
\begin{aligned}
& D_{i}=\chi_{i} P_{i}^{-\eta_{i}} \\
& S_{i}=S A_{i}+S N_{i} \\
& S N_{i}=\beta_{i} P_{i}^{\theta_{i}}\left(1-Z_{i}\right) \\
& S A_{i}=\left(1-h_{i}\right) \beta_{i}\left(v_{i} P_{i}\right)^{\theta_{i} Z_{i}} \\
& P_{i}=W P_{i}+\mu_{i} \\
& X_{i}=S_{i}-D_{i} \\
& X_{i}=v_{i}\left(W P_{i}\right)^{\omega_{i}}
\end{aligned}
$$

Data for the mussel PE model were obtained from

\begin{tabular}{|c|c|c|c|}
\hline Variable & Unit & Value & Source \\
\hline Production & $\mathrm{t}$ & 36493 & FAO (2014) \\
\hline Consumption & $\mathrm{t}$ & 67 & FAO (2014) \\
\hline Export quantity & $\mathrm{t}$ & 36518 & FAO (2014) \\
\hline Import quantity & $\mathrm{t}$ & 92 & FAO (2014) \\
\hline Export revenue & Million NZ\$ & 218.1 & Aquaculture New Zealand (2012) \\
\hline Domestic revenue & Million NZ\$ & 35 & Nixon (2003) \\
\hline Export price & $N Z \$ t^{-1}$ & 5718 & Aquaculture $\mathrm{Ne}$ \\
\hline Domestic price & $N Z \$ t^{-1}$ & 5089 & Estimated $^{\mathrm{a}}$ \\
\hline Supply elasticity & Unitless & 0.76 & Nixon (2003) \\
\hline Demand elasticity & Unitless & -0.29 & FAO (2014) \\
\hline Export elasticity & Unitless & -2.79 & Own estimation (see Appendix) \\
\hline \multicolumn{4}{|c|}{$\begin{array}{l}{ }^{a} \text { We assumed that domestic price is equal to international price minus trans- } \\
\text { portation costs. Transportation cost was reported at } 11 \% \text { of international price } \\
\text { (Wyatt 2011) }\end{array}$} \\
\hline
\end{tabular}
FAO statistics (Lem et al. 2014) and are presented in Table 3.
Table 3. Data inputs for the partial equilibrium model that was used to capture the societal effects, i.e. the changes in the producer and consumer surpluses that result from a price change of green-lipped mussels, which may be affected by the presence of Styela clava and Sabella spallanzanii

\section{Uncertainty analysis}

We conducted sensitivity analysis for the biological and economic parameters of the bioeconomic model within a singleand multi-parameter framework (Table 4). The single parameter framework shows how the resulting impacts will change if only 1 parameter is varied, while the multi-parameter framework will show how the resulting impacts will change if all model parameters are set to lower or higher values. The biological parameters that were tested were: (1) the ini- 
Table 4. Results of the uncertainty analysis for the biological and economic parameters of the bio-economic model for greenlipped mussel culture within a single- and multi-parameter framework. See 'Methods' for details

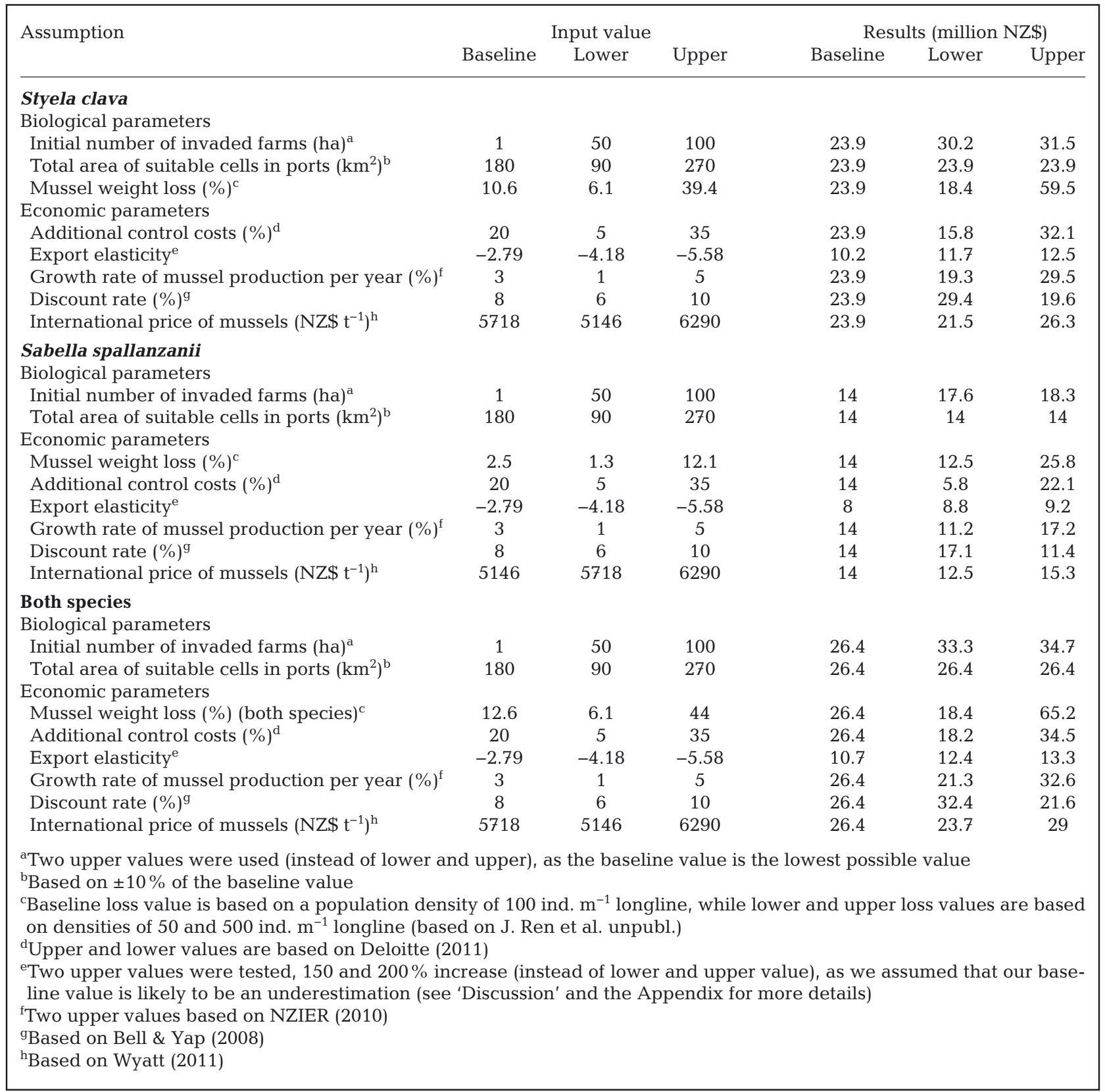

tial number of invaded cells of mussel farms, and (2) the total number of suitable cells in NZ seaports, which is needed to calculate the relative rate of spatial increase $\mathrm{yr}^{-1}$. Changing these 2 parameters will affect the initial density of the logistic function, leading to changes in the rate of spatial increase, which will ultimately affect the resulting economic impacts. For the economic parameters, we tested the sensitivity of the following parameters: (1) market price, (2) percentage of mussel weight loss (based on different pest population densities), (3) percentage of additional control costs, (4) export elasticity, (5) discount rate and (6) the annual growth rate of mussel production. In the multiparameter framework, fluctuations in market price (1), percentage of mussel weight loss (2) (based on different pest population densities), percentage of additional control costs (3), discount rate (5) and the annual growth rate of mussel production (6), were considered together. 


\section{RESULTS}

\section{Spatio-temporal pest spread}

The results from the spread model estimated that it will take up to 24 yr for Styela clava and Sabella spallanzanii to infest all mussel farms in NZ, assuming that 1 ha of mussel farm (out of 4747 ha) is initially infested. The highest annual infestation rate is realized in Year 11, when $19 \%$ of the farms are infested (Fig. 2).

\section{Direct economic impacts}

The total costs on producers due to mussel weight loss and additional control costs are estimated at \$23.9, 14 and 26.4 million for S. clava, S. spallanzanii, and both species combined over the course of $24 \mathrm{yr}$, respectively (Table 5). The impacts reach their maximal effect in Year 11 at \$4.6, 2.7 and 5.1 million $\mathrm{yr}^{-1}$ for $S$. clava, S. spallanzanii and both species, respectively (Fig. 3).

\section{Total societal economic impacts}

The impacts on social welfare are estimated at \$10.2, 8 and 10.7 million for S. clava, S. spallanzanii and both species, respectively (Table 5). The results show that the producers should be able to increase the selling prices and, therefore, transfer part of their losses to foreign consumers.

Table 5. (a) Total direct economic impacts on green-lipped mussel culture over the infestation period in million NZ\$, estimated from the partial budgeting model. (b) Total direct and indirect economic impacts (societal welfare) over the infestation period in million NZ\$, estimated from the partial equilibrium model

\begin{tabular}{|c|c|c|c|}
\hline $\begin{array}{l}\text { (a) Direct economic ir } \\
\text { Species }\end{array}$ & $\begin{array}{l}\text { apacts (prodi } \\
\text { Mussel } \\
\text { weight loss }\end{array}$ & $\begin{array}{l}\text { cer level) } \\
\text { Additional } \\
\text { cost }\end{array}$ & $\begin{array}{l}\text { Total } \\
\text { cost }\end{array}$ \\
\hline Styela clava & 13.1 & 10.8 & 23.9 \\
\hline Sabella spallanzanii & 3.1 & 10.9 & 14.0 \\
\hline Both & 15.5 & 10.9 & 26.4 \\
\hline \multicolumn{4}{|c|}{ (b) Direct and indirect economic impacts (market level) } \\
\hline Species & $\begin{array}{l}\text { Producer } \\
\text { surplus }\end{array}$ & $\begin{array}{l}\text { Consumer } \\
\text { surplus }\end{array}$ & $\begin{array}{c}\text { Total } \\
\text { societal welfare }\end{array}$ \\
\hline Styela clava & 10.2 & 0.001 & 10.2 \\
\hline Sabella spallanzanii & 8 & 0.005 & 8 \\
\hline Both & 10.7 & 0.001 & 10.7 \\
\hline
\end{tabular}

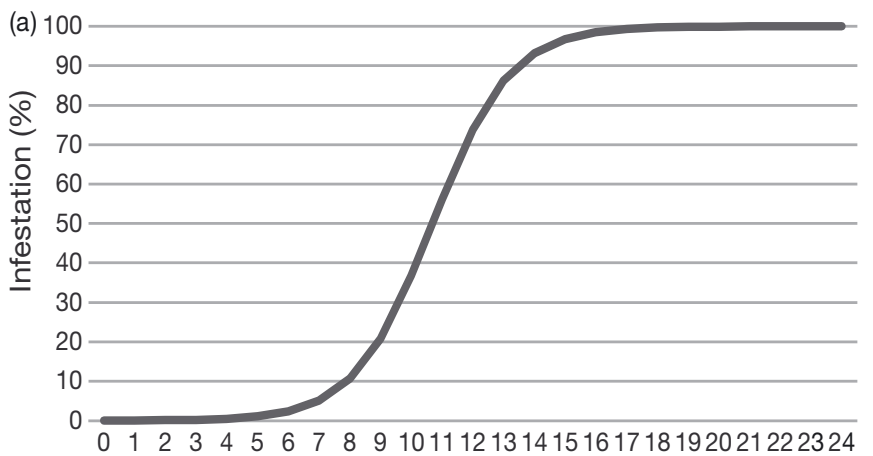

(b) 25

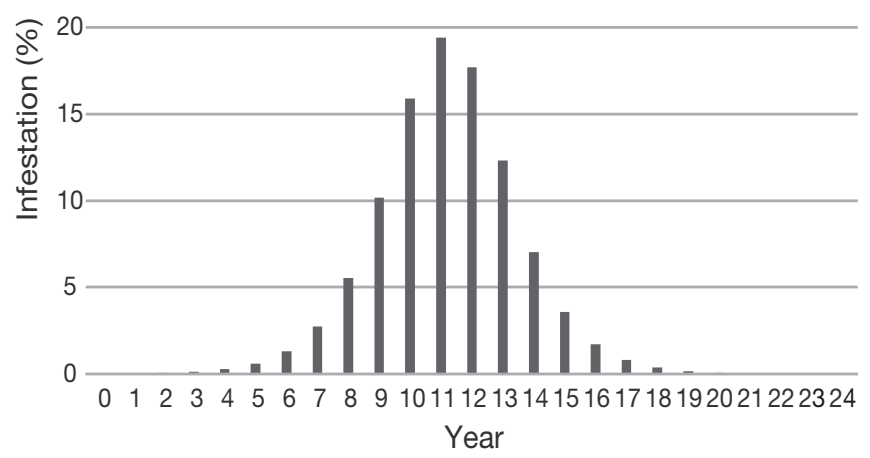

Fig. 2. (a) Cumulative percentage of invaded green-lipped mussel farms per year and (b) absolute percentage of mussel farms invaded by Styela clava and Sabella spallanzanii per year

\section{Uncertainty analysis}

Table 4 summarizes the results of the sensitivity analysis for the biological and economic parameters of the model. For the single parameter framework, changing the rate of mussel weight loss could significantly affect the resulting impacts. In contrast, changing the total suitable area of NZ seaports has no effect on the resulting impacts. The rest of the parameters, such as initial number of invaded farms, additional control costs, growth rate of mussel production $\mathrm{yr}^{-1}$, discount rate and international price of mussels, could have a moderate effect on the resulting impacts. In the multi-parameter framework analysis, the results showed that the lower value scenario will lead to economic impacts of $\$ 7.4,2.5$ and 7.4 million for S. clava, $S$. spallanzanii and both species, respectively, while the upper value scenario will lead to economic impacts of \$91.9, 56.7 and 99.7 million, for S. clava, S. spallanzanii and both species, respectively. 


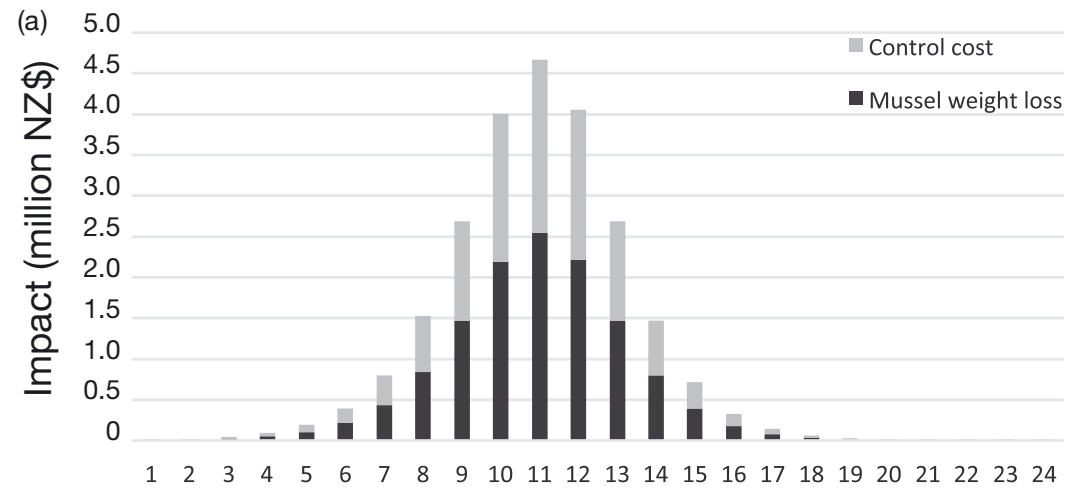

(b) 3.0

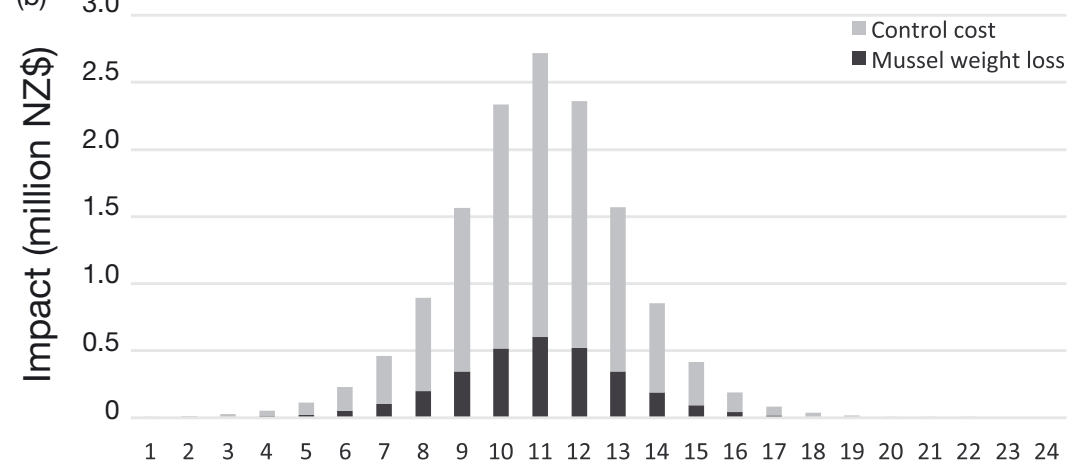

(c) 6.0

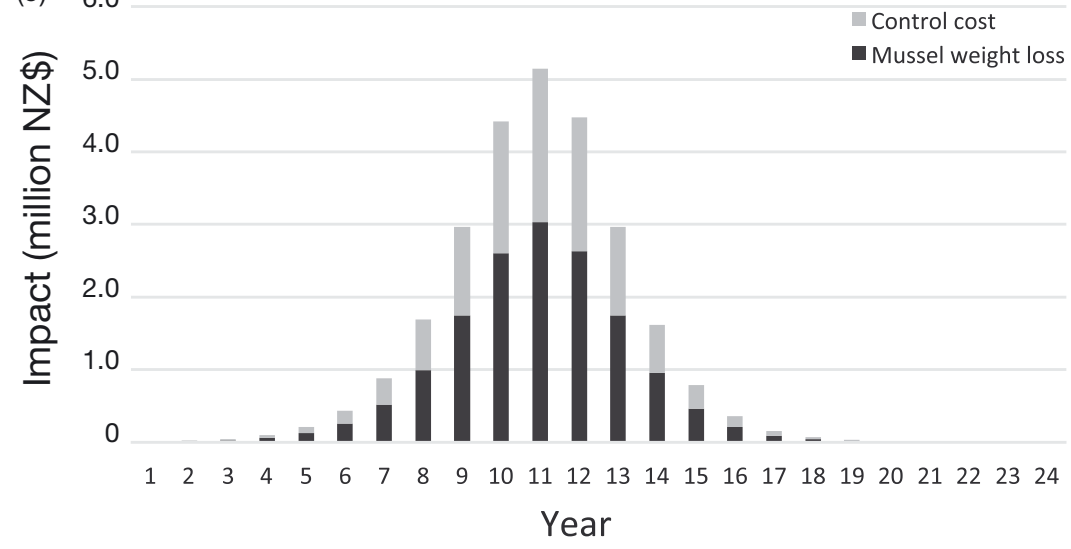

Fig. 3. Direct economic impacts on revenue of green-lipped mussel culture by (a) Styela clava, (b) Sabella spallanzanii and (c) both species per year

nominal value adjusted for inflation) to $\$ 288-354$ million by 2020, and to \$376-552 million by 2030 (EYTAS 2009, LECG 2010, NZIER 2010). Extrapolating these values means that by 2040, the revenues of the mussel industry could achieve $\sim \$ 647$ million on average. As such, our estimated impacts of S. clava and $S$. spallanzanii over 24 yr represent around $4 \%$ of the total industry revenue. The Northland Regional Council recently estimated that a management plan for $S$. spallanzanii that includes sustained control and education programmes with pathway management in place could cost around \$1.56 million over 50 yr. It was estimated that the programme will reduce the pest impacts by $\$ 3.58$ million over the same period (NRC 2017). Using the same ratios, this means that a national programme that cost \$11.5 million could prevent the total estimated impacts in our study.

At the market level, where aggregated supply and demand interactions and fluctuations of mussel price are considered, the expected societal impacts are estimated at $\$ 10.2,8$ and 10.7 million for S. clava, S. spallanzanii and both species, respectively. Our results showed that reducing the density of S. clava and S. spallanzanii individuals on the mussel longlines will significantly reduce their potential impacts (i.e. output loss and additional control costs). For instance, reducing the number of S. clava and S. spallanzanii from 500 to 100 ind. $\mathrm{m}^{-1}$ of longline could reduce the economic impacts by 60,44 and $60 \%$ for S. clava, S. spallanzanii and both species, respectively.

\section{DISCUSSION}

Our analyses showed that uncontrolled spread of Styela clava and Sabella spallanzanii will lead to large direct economic impacts at the green-lipped mussel producer level estimated at $\$ 23.9$ million for S. clava, \$14 million for S. spallanzanii and \$26.4 million for both species combined over $24 \mathrm{yr}$, with large uncertainty around these estimates of \$7.4-91.9, 2.5-56.7 and 7.4-99.7 million, respectively. Revenues to the mussel industry in 2010 were \$239 million. These are predicted to increase (in real \$NZ; i.e.
The societal impacts at the market level were lower than the direct impacts at the producer level. This is because the direct impacts are the impacts on the producer revenues, while the societal impacts are the changes to the surpluses of the producers and consumers. The producer surplus is estimated by subtracting the variable costs from the producer revenues and adjusting it to the new market prices, while the consumer surplus is estimated after adjusting it to the new market prices. In addition, in the PE market model, the producers were predicted to be able to increase the selling export price and, there- 
fore, transfer part of their losses to foreign consumers. The export (i.e. excess demand) elasticity parameter in the PE model is responsible for estimating the possible reduction in world demand for NZ exports due to an increase in the world price (NZIER 2011). This parameter was estimated at -2.79 (see the Appendix), which means that if the NZ producers increase the price by $1 \%$, the foreign demand will decrease by $2.79 \%$. The estimated value of the export elasticity reflects NZ pricing power in the world mussel market. It is generally accepted that a small country such as NZ has limited impact over the world price, which is translated in technical terms as a large export elasticity. Here in our model, the export elasticity was estimated at a relatively low value, which suggests that NZ exerts some degree of power in the world mussel market, and this in turn will lead to transferring a large part of the impacts to the rest of the world. This is mainly due to its large supply to the world market ( $18 \%$ of world supply; Lem et al. 2014). The estimated pricing power of NZ over the world market (i.e. relative low value of export elasticity) may be an overestimation because it did not account for counter effects that may reduce the NZ pricing power. For example, rising competition from similar commodities may affect the pricing power (i.e. changes in NZ product differentiation abilities). In addition, foreign supply responses to price changes were assumed to be similar to those in NZ due to a lack of information (NZIER 2011). Our sensitivity analysis showed that, for S. clava, increasing the export elasticity by $50 \%$ or doubling its value will increase the market impacts by 14 and $22 \%$, respectively. It is therefore important to maintain NZ mussel exports after the expected price increase and avoid any bans on exports, or foreign policies that could reduce NZ exports. Also, increasing the differentiation of NZ mussels from competing products could reduce the likelihood that consumers will shift to them.

In our analysis, S. spallanzanii had much lower impacts on mussel production than S. clava. However, we suspect that the impacts of $S$. spallanzanii are underestimated. This is because there were no data available to parameterize the biofouling-aquaculture ecosystem model for some $S$. spallanzanii food sources (e.g. smaller plankton and suspended matter fractions), while data for $S$. clava's principal food source (i.e. phytoplankton) was relatively complete (J. Ren et al. unpubl.). A consequence is less accurate predictions for impacts of $S$. spallanzanii on mussel weight.

The model considers only direct removal of food from the water column by S. clava and S. spallan- zanii. The long tubes (up to $85 \mathrm{~cm}$ length) and large branchial crown ('fan') of S. spallanzanii (Read et al. 2011) mean that adult worms will extend further than mussels or S. clava from the longline and may form dense 'canopies' that pre-empt food consumption by the smaller species. S. spallanzanii 'canopies' have demonstrated effects on the recruitment, survival and growth of other biofouling organisms (Holloway \& Keough 2002a,b). The model also does not account for potential overgrowth (smothering) and dislodgement of mussel stock by the 2 species (Carver et al. 2003, Forrest \& Atalah 2017). Our model can be considered as a simplified version of reaction diffusion models, and the relative rate of increase $r$ of the invaded area can be seen as an integrated estimate of different types of dispersal (e.g. natural and anthropogenic dispersal). In addition, as the model is spatially implicit, this implies that the model does not account for realistic distribution of the host mussel farms.

As we have shown, the direct economic costs are greatest when the 2 invaders co-occur on production systems. This is important because, while farmers may be able to adjust their operations to manage a single invasive species or adapt to reduced profitability, the cumulative effects of successive invasions may push margins or market prices to unsustainable levels. Most risk assessments treat threats from different invasive species in isolation from one another, but there is clear need to consider how they may add to the existing financial burden of other pests (Fletcher et al. 2013, Forrest \& Atalah 2017).

Options for managing the impacts of $S$. clava and $S$. spallanzanii on the green-lipped mussel industry include taking no action, containment or local elimination of the pest(s). Eradication at a national level is no longer an option for either organism due to the number of locations at which these species have become established. Containment can be achieved by preventing natural and human-mediated dispersal (i.e. through movement of fouled vessels and aquaculture equipment and stock) to uninfested areas. On-going surveillance in uninfested areas and monitoring of potential vectors can help in the timely detection and response to new populations (Floerl et al. 2009, 2016).

Several regional programmes within NZ are currently engaged in attempts to prevent further spread of both species (Fletcher 2014, Grayling 2015, Waikato Regional Council 2015). These have implemented a raft of measures for inspection and treatment of infested vessels and equipment (Coutts \& Forrest 2007, Atalah et al. 2016, Morrisey et al. 2016) and local population control, the latter with varying 
degrees of success (Gust et al. 2008, Inglis et al. 2009, Fletcher 2014). In addition, the aquaculture industry itself is improving its planning for and management of biosecurity threats by strengthening protocols for on-farm management of stock and equipment hygiene (Georgiades et al. 2016, Ministry for Primary Industries 2016a). To be effective, these measures will need to be sustained over the long term and will impose significant on-going costs on industry, local authorities and the public. Greater investment in prevention and early intervention against invasive species can obviate the need for expensive long-term commitments to control over indefinite time frames (Myers et al. 2000, Leung et al. 2002). However, managers are reluctant to make investments at these stages, when the risks are uncertain and the effectiveness and benefits of intervention are unclear, preferring to act when there are likely to be more definitive outcomes and public support (Finnoff et al. 2007).

Management of $S$. spallanzanii in NZ provides a salient example of this dilemma. Soon after it was detected in the Port of Lyttelton, the government funded a $5 \mathrm{yr}$, \$3.5 million programme to eliminate it. Despite the apparent initial success of these measures (Inglis et al. 2009), they were discontinued after 7 mo when a second population was detected at several dispersed locations in Auckland (Read et al. 2011). At the time, withdrawal of the funding was justified on the basis that the costs of continuing and extending the measures to Auckland were not warranted given the uncertainty around the impacts of $S$. spallanzanii (MAF BNZ 2010). Subsequent uncontained spread has meant that the defensive costs of control and impacts are now being borne by other public and private sectors and, as our study shows, are likely to be significantly larger over the long term than the initial allocation of public funding. This degraded situation calls for additional efforts from the government to strengthen the measures that are related to management of vectors and surveillance of high value sites. Quantifying the anticipated economic impacts of invasive marine species is needed early in the invasion process to justify the proper strength, timing and level of biosecurity intervention and its cost-effectiveness, despite uncertainties.

Acknowledgements. This work benefitted from a shellfish dynamic energy budget ecosystem model developed by Jeffrey Ren and Chris Woods (National Institute of Water and Atmospheric Research, NIWA), and from discussions with both researchers. T.S. and G.J.I. received funding for the work from NIWA under Coasts and Oceans Programme 6:
2016/17 SCI (Project CDPD1504) and Ministry for Business, Industry and Employment Contract CO1X1511 - 'What's at stake?'

\section{LITERATURE CITED}

Adams C, Shumway S, Whitlatch R, Getchis T (2011) Biofouling in marine molluscan shellfish aquaculture: a survey assessing the business and economic implications of mitigation. J World Aquacult Soc 42:242-252

Aquaculture New Zealand (2012) New Zealand Aquaculture-a sector overview with key facts, statistics and trends. Aquaculture New Zealand, Nelson. http://www.aquaculture.org.nz/wp-content/uploads/2012/05/ NZ-Aquaculture-Facts-2012.pdf

Arsenault G, Davidson J, Ramsay A (2009) Temporal and spatial development of an infestation of Styela clava on mussel farms in Malpeque Bay, Prince Edward Island, Canada. Aquat Invasions 4:189-194

Atalah J, Brook R, Cahill PM, Fletcher LA, Hopkins G (2016) It's a wrap: encapsulation as a management tool for marine biofouling. Biofouling 32:277-286

Bell B, Yap M (2008) Report to Biosecurity New Zealand on valuing the coastal marine environment: assessing the marginal dollar value losses of an estuarine ecosystem from an aggressive alien invasive crab. Follow up survey of Pauatahanui Inlet. Working Paper No 8, FRST Project NIMMO501 - Valuing Biodiversity. Nimmo-Bell, Wellington

Carver C, Chisholm A, Mallet al. (2003) Strategies to mitigate the impact of Ciona intestinalis (L.) biofouling on shellfish production. J Shellfish Res 22:621-631

* Cook D, Fraser R, Waage J, Thomas M (2011) Prioritising biosecurity investment between agricultural and environmental systems. J Verbrauch Lebensm 6:3-13

Coutts A, Forrest B (2007) Development and application of tools for incursion response: lessons learned from the management of the fouling pest Didemnum vexillum. J Exp Mar Biol Ecol 342:154-162

Currie DR, McArthur MA, Cohen BF (2000) Reproduction and distribution of the invasive European fanworm Sabella spallanzanii (Polychaeta: Sabellidae) in Port Phillip Bay, Victoria, Australia. Mar Biol 136:645-654

Davis MH, Davis ME (2006) Styela clava (Tunicata: Ascidiacea) a new edition to the fauna of New Zealand. Porcupine Mar Nat Hist Soc Newsl 20:19-22

Deloitte (2011) Styela clava: economic impact assessment. Report to the Ministry of Agriculture \& Forestry, Wellington

EYTAS (Ernst \& Young Transaction Advisory Services) (2009) New Zealand aquaculture: industry growth scenarios. Report to Aquaculture New Zealand, Wellington

FAO (Food and Agriculture Organization of the United Nations) (2014) The state of world fisheries and aquaculture 2014. FAO, Rome

Finnoff D, Shogren JF, Leung B, Lodge D (2007) Take a risk: preferring prevention over control of biological invaders. Ecol Econ 62:216-222

* Fitridge I, Dempster T, Guenther J, de Nys R (2012) The impact and control of biofouling in marine aquaculture: a review. Biofouling 28:649-669

Fletcher LM (2014) Background information on the Mediterranean fanworm, Sabella spallanzanii, to support regional response decisions. Cawthron Rep No 2479A. Cawthron Institute, Nelson

FFletcher LM, Forrest BM, Bell JJ (2013) Impacts of the in- 
vasive ascidian Didemnum vexillum on green-lipped mussel Perna canaliculus aquaculture in New Zealand. Aquacult Environ Interact 4:17-30

Floerl O, Inglis GJ, Dey K, Smith A (2009) The importance of transport hubs in stepping-stone invasions. J Appl Ecol 46:37-45

Floerl O, Inglis GJ, Diettrich J (2016) Incorporating human behaviour into the risk-release relationship for invasion vectors: why targeting only the worst offenders can fail to reduce spread. J Appl Ecol 53:742-750

Forrest BM, Atalah J (2017) Significant impact from blue mussel Mytilus galloprovincialis biofouling on aquaculture production of green-lipped mussels in New Zealand. Aquacult Environ Interact 9:115-126

Forrest B, Blakemore KA (2006) Evaluation of treatments to reduce the spread of a marine plant pest with aquaculture transfers. Aquaculture 257:333-345

Georgiades E, Fraser R, Jones B (2016) Options to strengthen on-farm biosecurity management for commercial and non-commercial aquaculture. Tech Pap No 2016/47. Ministry for Primary Industries, Wellington

Giangrande A, Pierri C, Fanelli G, Schirosi R, Licciano M, Stabili L (2014) Rearing experiences of the polychaete Sabella spallanzanii in the Gulf of Taranto (Mediterranean Sea, Italy). Aquacult Int 22:1677-1688

Giles H, Pilditch CA (2006) Effects of mussel (Perna canaliculus) biodeposit decomposition on benthic respiration and nutrient fluxes. Mar Biol 150:261-271

Grayling S (2015) Small-scale management programme Mediterranean fanworm (Sabella spallanzanii). Bay of Plenty Regional Council, Toi Moana

Gust N, Inglis G, Floerl O, Peacock L, Denny C, Forrest B (2008a) Assessment of population management trial options for Styela clava at three locations. NIWA Client Report: CHC2007-094 prepared for MAF-Biosecurity NZ, Project BSP21705. NIWA, Christchurch

Gust N, Inglis G, Floerl O, Peacock L, Denny C, Forrest B (2008b) Assessment of population management options for Styela clava. Tech Pap No: 2009/04. Ministry of Agriculture and Forestry, Biosecurity New Zealand, Wellington

Holloway M, Keough MJ (2002a) Effects of an introduced polychaete, Sabella spallanzanii, on the development of epifaunal assemblages. Mar Ecol Prog Ser 236:137-154

Holloway MG, Keough MJ (2002b) An introduced polychaete affects recruitment and larval abundance of sessile invertebrates. Ecol Appl 12:1803-1823

Hulme PE, Pyšek P, Jarošík V, Pergl J, Schaffner U, Vilà M (2013) Bias and error in understanding plant invasion impacts. Trends Ecol Evol 28:212-218

Inglis GJ, Floerl O, Seaward K, Woods C, Read G, Peacock L (2009) Sabella local elimination programme - Phase 1. Final Assessment Report, Research Project MAF11199. Prepared for MAF Biosecurity New Zealand, Wellington

Johnson PR (1977) The elasticity of foreign demand for US agricultural products. Am J Agric Econ 59:735-736

Katsanevakis S, Wallentinus I, Zenetos A, Leppäkoski E and others (2014) Impacts of invasive alien marine species on ecosystem services and biodiversity: a pan-European review. Aquat Invasions 9:391-423

Lacoste E, Gaertner-Mazouni N (2015) Biofouling impact on production and ecosystem functioning: a review for bivalve aquaculture. Rev Aquacult 7:187-196

Lambert C, Lambert G (1998) Nonindigenous ascidians in southern California harbors and marinas. Mar Biol 130: 675-688

Lambert CC, Lambert G (2003) Persistence and differential distribution of nonindigenous ascidians in harbors of the Southern California Bight. Mar Ecol Prog Ser 259: $145-161$

LECG (Law \& Economic Consulting Group) (2010) Aquaculture in New Zealand: supplementary analysis for 'New Space' settlement obligation. Commissioned report to the Ministry of Fisheries, Wellington

Lem A, Bjorndal T, Lappo A (2014) Economic analysis of supply and demand for food up to 2030 - special focus on fish and fishery products. FAO Fisheries and Aquaculture Circular No 1089. FIPM/C1089. FAO, Rome

* Lemmens JWTJ, Clapin G, Lavery P, Cary J (1996) Filtering capacity of seagrass meadows and other habitats of Cockburn Sound, Western Australia. Mar Ecol Prog Ser 143:187-200

* Leung B, Lodge DM, Finnoff D, Shogren JF, Lewis MA, Lamberti G (2002) An ounce of prevention or a pound of cure: bioeconomic risk analysis of invasive species. Proc R Soc Lond B 269:2407-2413

* Lodge DM, Simonin PW, Burgiel SW, Keller RP and others (2016) Risk analysis and bioeconomics of invasive species to inform policy and management. Annu Rev Environ Resour 41:453-488

MAF BNZ (Ministry of Agriculture and Forestry Biosecurity New Zealand) (2010) Mediterranean fanworm (Sabella spallanzanii) questions and answers. http:// www.mpi.govt.nz/protection-and-response/finding-andreporting-pests-and-diseases/pest-and-disease-search? article $=1489$

Ministry for Primary Industries (2016a) Aquaculture biosecurity handbook. Assisting New Zealand's commercial and non-commercial aquaculture to minimise on-farm biosecurity risk. Ministry for Primary Industries, Wellington

Ministry for Primary Industries (2016b) Situation and outlook for primary industries 2016. Ministry for Primary Industries, Wellington

Morrisey D, Plew D, Seaward K (2011) Aquaculture Readiness Data Phase II (09 11719). MAF Tech Pap No 2011/68. Ministry of Agriculture and Forestry, Wellington

Morrisey DJ, Depree CV, Hickey CW, McKenzie DS and others (2016) Rapid treatment of vessels fouled with an invasive polychaete, Sabella spallanzanii, using a floating dock and chlorine as a biocide. Biofouling 32 : 135-144

Myers JH, Simberloff D, Kuris AM, Carey JR (2000) Eradication revisited: dealing with exotic species. Trends Ecol Evol 15:316-320

Nixon C (2003) Ngai Tahu Seafood-a case study in business development. NZ Trade Consortium Working Paper No 25. NZIER, Wellington

NRC (Northland Regional Council) (2017) Northland regional pest and marine pathway management plan cost benefit analysis. Northland Regional Council Report. NRC, Whangārei

NZIER (New Zealand Institute of Economic Research) (2005) Sea squirt alert: economic impact assessment of Styela clava. Report to MAF Biosecurity New Zealand. NZIER, Wellington

NZIER (2010) The net economic benefit of aquaculture growth in New Zealand-scenarios to 2025. Final Report to Aquaculture New Zealand. NZIER, Wellington

NZIER (2011) Review of export elasticities. Working Pap 2011/4. NZIER, Wellington

Ojaveer H, Galil BS, Campbell ML, Carlton JT and others (2015) Classification of non-indigenous species based on their impacts: considerations for application in marine 
management. PLOS Biol 13:e1002130

Padilla DK, McCann MJ, Shumway SE (2011) Marine invaders and bivalve aquaculture: sources, impacts, and consequences In: Shumway SE (ed) Shellfish aquaculture and the environment. Wiley-Blackwell, Oxford

*Pochon X, Atalah J, Wood SA, Hopkins GA, Watts A, Boedeker C (2015) Cladophora ruchingeri (C. Agardh) Kützing, 1845 (Cladophorales, Chlorophyta): a new biofouling pest of green-lipped mussel Perna canaliculus (Gmelin, 1791) farms in New Zealand. Aquat Invasions 10:123-133

Read G, Handley S (2004) New alien mudworm now becoming a pest in longline mussels. Water Atmos 12:30-31

Read G, Inglis GJ, Stratford P, Ahyong ST (2011) Arrival of the alien fanworm Sabella spallanzanii (Gmelin, 1791) (Polychaeta: Sabellidae) in two New Zealand harbours. Aquat Invasions 6:273-279

Ren JS, Ross AH, Hadfield MG, Hayden BJ (2010) An ecosystem model for estimating potential shellfish culture production in sheltered coastal waters. Ecol Model 221: 527-539

Richardson DM, Pyšek P (2008) Fifty years of invasion ecology - the legacy of Charles Elton. Divers Distrib 14: 161-168

Riding T, Woods C, Wilkens S, Inglis G (2015) Marine surveillance annual report. Surveillance 42:56-59

Robinet C, Kehlenbeck H, Kriticos DJ, Baker RHA and others (2012) A suite of models to support the quantitative assessment of spread in pest risk analysis. PLOS ONE 7:e43366

Simberloff D, Martin JL, Genovesi P, Maris V and others (2013) Impacts of biological invasions: what's what and the way forward. Trends Ecol Evol 28:58-66

Soliman T, Mourits MCM, Oude Lansink AGJM, van der
Werf W (2010) Economic impact assessment in pest risk analysis. Crop Prot 29:517-524

Soliman T, Mourits MCM, Oude Lansink AGJM, van der Werf W (2012) Quantitative economic impact assessment of an invasive plant disease under uncertainty-a case study for potato spindle tuber viroid (PSTVd) invasion into the European Union. Crop Prot 40:28-35

Surkov IV, Oude Lansink AGJM, van der Werf W (2009) The optimal amount and allocation of sampling effort for plant health inspection. Eur Rev Agric Econ 36: 295-320

Thompson R, MacNair N (2004) An overview of the clubbed tunicate (Styela clava) in Prince Edward Island. Tech Rep 234. PEI Department of Agriculture, Fisheries, Aquaculture and Forestry, Charlottetown

Waikato Regional Council (2015) 2015-2025 Long term plan. Waikato Regional Council, Hamilton

Watson DI, Shumway SE, Whitlatch RB (2009) Biofouling and the shellfish industry. In: Shumway SE, Rodrick GE (eds) Shellfish safety and quality. Woodhead Publishing, Cambridge, p 317-337

Williams SL, Grosholz ED (2008) The invasive species challenge in estuarine and coastal environments: marrying management and science. Estuaries Coasts 31:3-20

*Woods CMC, Floerl O, Hayden BJ (2012) Biofouling on Greenshell ${ }^{\mathrm{TM}}$ mussel (Perna canaliculus) farms: a preliminary assessment and potential implications for sustainable aquaculture practices. Aquacult Int 20:537-557

Woods C, Seaward K, Inglis G (2015) Marine high risk site surveillance: annual report for all ports and marinas 2014-15 (Project 12099). MPI Tech Publ No 2015/23. Ministry for Primary Industries, Wellington

Wyatt S (2011) Economic impact of Coromandel aquaculture. Hauraki-Coromandel Development Group, Wellington

\section{APPENDIX}

\section{Calculation of export elasticity}

We calculated the export (excess demand) elasticity of New Zealand (NZ) (Surkov et al. 2009) as follows:

$$
w=\sum_{m} e_{m} \varphi_{m}\left(\frac{D_{m}}{E_{m}} \eta_{m}-\frac{S_{m}}{E_{m}} \theta_{m}\right)
$$

where $w$ is the export (excess demand) elasticity in $\mathrm{NZ}_{i} e_{m}$ is the price transmission elasticity from NZ to the export country $m_{i} \varphi_{m}$ is the weight of country $m$ in the total export of NZ; $D_{m}$ is the demand in the $m^{\text {th }}$ country for NZ mussels; $S_{m}$ is the supply to country $m$ of mussels from all regions other than $\mathrm{NZ}_{i} E_{m}$ is the total export of mussels from NZ; and $\eta_{m}$ and $\theta_{m}$ are, respectively, demand and supply elasticities of mussels in country $m$.

Table A1. Values used to parameterize the export elasticity equation (Eq. A1). ROW: rest of world

\begin{tabular}{|c|c|c|c|c|c|c|c|c|}
\hline Parameter & & Hong Kong & Spain & Australia & South Korea & US & ROW & Total \\
\hline Price transmission elasticity ${ }^{\mathrm{a}}$ & $e$ & 1 & 1 & 1 & 1 & 1 & 1 & \\
\hline Country weight $(\%)^{b}$ & $\varphi$ & 6 & 9 & 10 & 10 & 33 & 32 & \\
\hline Country demand (million NZ $\$)^{\mathrm{b}}$ & $D$ & 12.6 & 18.6 & 22.3 & 22.9 & 72.6 & 69.1 & \\
\hline Supply to country (except NZ) (million NZ\$) ${ }^{\mathrm{C}}$ & $S$ & 11.7 & 11.8 & 22.1 & 44.2 & 72.7 & 553.9 & \\
\hline Total export from NZ (million NZ\$) ${ }^{\mathrm{b}}$ & $E$ & 218 & 218 & 218 & 218 & 218 & 218 & \\
\hline Demand elasticity $^{\mathrm{C}}$ & $\eta$ & -0.29 & -0.29 & -0.29 & -0.29 & -0.29 & -0.29 & \\
\hline Supply elasticity & $\theta$ & 0.76 & 0.76 & 0.76 & 0.76 & 0.76 & 0.76 & \\
\hline Export elasticity & $\boldsymbol{w}$ & -0.06 & -0.07 & -0.11 & -0.18 & -0.35 & -2.02 & -2.79 \\
\hline
\end{tabular}

Editorial responsibility: Peter Cranford, Dartmouth, Nova Scotia, Canada
Submitted: July 25, 2017; Accepted: November 6, 2017

Proofs received from author(s): December 21, 2017 